\title{
Screening For Islet Cell Antibodies In Non-Diabetic Siblings of Children With Type I Diabetes Mellitus
}

\author{
Basma A. Ali, Suzan M. Omar, Noha A. Hussain and Tarek M. Osman \\ Department of Pediatrics, El-Minia Faculty of Medicine
}

\begin{abstract}
Type I Diabetes Mellitus (TIDM) is the most common chronic metabolic autoimmune disease. Aim of the work: To estimate serum levels of Islet cell antibodies (ICA) in first-degree relatives of type I diabetic children. Subjects and Methods: Study Design: This study was a prospective case-control hospital-based study carried upon 120 children randomly selected during the period from January 2016 till August 2016 after approval of the ethical committee of the Faculty of Medicine, Minia University. Results: This table shows insignificant differences between group I and group II regarding age, gender, residence, weight, height, and BMI centiles where $(\mathrm{P}>0.05)$. Finally, ICA positivity had a significant moderate negative correlation with fasting C-peptide
\end{abstract}

Keywords: Type I Diabetes Mellitus, chronic metabolic, Islet cell antibodies

\section{Introduction}

Type I Diabetes Mellitus (TIDM) is the most common chronic metabolic autoimmune disease $^{(\mathbf{1})}$. It is characterized by Hyperglycemia due to infiltration of lymphocytes in the pancreas causing destruction of insulinproducing beta-cells ${ }^{(2)}$.

Histological analysis of the pancreas from patients with TIDM shows immunological activity limited to insulin-containing islets, including infiltration by activated lymphocytes, antibodies and components of the complement system. These histological findings are consistent with TIDM being an immunemediated disease ${ }^{(3)}$. Further evidence came from studies showing that TIDM is characterized by the presence of antibody (humoral) and T-cell (cellular) responses to islet proteins (antigens). Immune responses to these antigens predate the clinical onset of diabetes, giving further support for an immune etiology to TIDM ${ }^{(4)}$.

Early studies primarily of first-degree relatives followed over time demonstrate that islet cell autoantibodies may predict T1DM. First degree relatives of type 1 diabetic patients have provided an excellent study population for defining risk factors for the progression to
T1DM because of the increased disease incidence in this group ${ }^{(5)}$.

\section{Aim of the work}

To estimate serum levels of Islet cell antibodies (ICA) in first degree relatives of type I diabetic children.

\section{Subjects and Methods Study Design:}

This study was a prospective case control hospital based study carried upon 120 children randomly selected during the period from January 2016 till August 2016 after approval of the ethical committee of Faculty of Medicine, Minia University.

We had an oral approve from every caregiver of the studied children to be enrolled in this study.

\section{Study Participants:}

The studied children were grouped as following:

Group I: included 60 children with a first degree relative with T1DM who had regular follow up in the diabetes outpatient's clinic, Minia University Maternity and Children Hospital. They were 25 (41.67\%) male and 35 $(58.33 \%)$ female with a mean age of $7.1 \pm 4.4$ years old. 
Group II: included 60 apparently healthy children with negative history of T1DM in their siblings, age and sex matched to the previous group. They were 27 (45\%) male and 33 (55\%) female with a mean age of $7.9 \pm 3.6$ years old.

The inclusion criteria:

Absence of diabetes as regaed criteria of ADA,
(2018) which are:

\section{The exclusion criteria:}

- $\quad$ Presence of any chronic illness.

- Presence of any syndromes.

- History of any drug intake.

- Refusal to participate in the study.

\section{Results}

Table (1) Comparison between the studied groups as regard some demographic and clinical data.

\begin{tabular}{|c|c|c|c|}
\hline Demographic Datum & $\begin{array}{c}\text { GROUP I } \\
\text { (FIRST DEGREE } \\
\text { OF T1D) } \\
\text { N=60 } \\
\end{array}$ & $\begin{array}{c}\text { GROUP II } \\
\text { (CONTROL) } \\
\text { N=60 }\end{array}$ & $\begin{array}{c}\text { P- } \\
\text { VALUE }\end{array}$ \\
\hline Age (years): Mean \pm SD & $7.1 \pm 4.4$ & $7.9 \pm 3.6$ & 0.25 \\
\hline $\begin{array}{ccc}\text { Gender: } & \text { Males } & \text { No }(\%) \\
& \text { Females } & \text { No }(\%)\end{array}$ & $\begin{array}{l}25(42.6 \%) \\
35(58.4 \%)\end{array}$ & $\begin{array}{l}27(45 \%) \\
33(55 \%)\end{array}$ & 0.71 \\
\hline $\begin{array}{lrl}\text { Residence: } & \text { Rural } & \text { No (\%) } \\
\text { Urban } & \text { No (\%) }\end{array}$ & $\begin{array}{l}33(55 \%) \\
27(45 \%)\end{array}$ & $\begin{array}{l}42(70 \%) \\
18(30 \%)\end{array}$ & 0.09 \\
\hline $\begin{array}{l}\text { Weight centile }(\mathrm{kg}): \\
<\mathbf{5}^{\text {th }} \text { percentile } \quad \text { No }(\%) \\
5^{\text {th }}: \mathbf{9 5}^{\text {th }} \text { percentile No }(\%) \\
>\mathbf{9 5}^{\text {th }} \text { percentile } \quad \text { No }(\%)\end{array}$ & $\begin{array}{l}5(8.4 \%) \\
48(80 \%) \\
7(11.6 \%)\end{array}$ & $\begin{array}{c}4(6.6 \%) \\
50(83.4 \%) \\
6(10 \%)\end{array}$ & 0.56 \\
\hline $\begin{array}{l}\text { Height centile }(\mathrm{cm}): \\
<\mathbf{5}^{\text {th }} \text { percentile } \quad \text { No }(\%) \\
5^{\text {th }}: 95^{\text {th }} \text { percentile No }(\%) \\
>95^{\text {th }} \text { percentile } \quad \text { No }(\%)\end{array}$ & $\begin{array}{l}7(11.6 \%) \\
45(75 \%) \\
8(13.4 \%)\end{array}$ & $\begin{array}{c}3(5 \%) \\
51(85 \%) \\
6(10 \%)\end{array}$ & 0.06 \\
\hline $\begin{array}{cc}\text { Body mass index }(\text { BMI }) & \text { centile }(\mathrm{kg} / \mathrm{m} 2): \\
<5^{\text {th }} \text { percentile } & \text { No }(\%) \\
5^{\text {th }}: 95^{\text {th }} \text { percentile } & \text { No }(\%) \\
>\mathbf{9 5}^{\text {th }} \text { percentile } & \text { No }(\%)\end{array}$ & $\begin{array}{c}6(10 \%) \\
47(78.4 \%) \\
7(11.6 \%)\end{array}$ & $\begin{array}{l}4(6.6 \%) \\
51(85 \%) \\
5(8.4 \%)\end{array}$ & 0.38 \\
\hline
\end{tabular}

T1D=type 1 diabetes; NO=number; $\mathrm{SD}=$ =standard deviation.

This table shows insignificant differences between group I and group II regarding age, gender, residence, weight, height and BMI centiles where $(\mathrm{P}>0.05)$. 
Table (2): Comparison between the studied groups as regard some family history variables.

\begin{tabular}{|c|c|c|c|}
\hline VARIABLE & $\begin{array}{l}\text { GROUP I } \\
\quad \mathrm{N}=60\end{array}$ & $\begin{array}{l}\text { GROUP II } \\
\mathbf{N}=60\end{array}$ & P-Value \\
\hline $\begin{array}{lll}\text { Birth order } & 1^{\text {st }} & \text { No }(\%) \\
& 2^{\text {nd }} & \text { No }(\%) \\
& 3^{\text {rd }} & \text { No }(\%) \\
& \text { More } & \text { No }(\%)\end{array}$ & $\begin{array}{l}12(20 \%) \\
22(36.6 \%) \\
13(21.7 \%) \\
13(21.7 \%)\end{array}$ & $\begin{aligned} 22(36.6 \%) \\
19(31.7 \%) \\
7(11.7 \%) \\
12(20 \%)\end{aligned}$ & 0.17 \\
\hline Family size: Mean \pm SD & $5.3 \pm 1.3$ & $5 \pm 0.7$ & 0.11 \\
\hline $\begin{array}{cc}\text { Father occupation: Farmer } & \text { No }(\%) \\
\text { Worker } & \text { No }(\%) \\
\text { Employee } & \text { No }(\%) \\
\text { None } & \text { No }(\%) \\
\end{array}$ & $\begin{array}{c}20(33.4 \%) \\
25(41.6 \%) \\
10(16.6 \%) \\
5(8.4 \%)\end{array}$ & $\begin{array}{l}27(45 \%) \\
18(30 \%) \\
9(15 \%) \\
6(10 \%) \\
\end{array}$ & 0.51 \\
\hline $\begin{array}{cc}\text { Mother occupation: House wife No }(\%) \\
\text { Works } & \text { No }(\%)\end{array}$ & $\begin{array}{c}56(93.4 \%) \\
4(6.6 \%)\end{array}$ & $\begin{array}{l}51(85 \%) \\
9(15 \%)\end{array}$ & 0.14 \\
\hline $\begin{array}{cc}\text { Father education: Educated } & \text { No (\%) } \\
\text { Illiterate } & \text { No }(\%)\end{array}$ & $\begin{array}{l}22(36.6 \%) \\
38(63.4 \%)\end{array}$ & $\begin{array}{l}15(25 \%) \\
45(75 \%)\end{array}$ & 0.17 \\
\hline $\begin{array}{cc}\text { Mother education:Educated } & \text { No }(\%) \\
\text { Illiterate } & \text { No }(\%)\end{array}$ & $\begin{array}{l}23(38.4 \%) \\
37(61.6 \%)\end{array}$ & $\begin{array}{l}15(25 \%) \\
45(75 \%)\end{array}$ & 0.12 \\
\hline $\begin{array}{cc}\text { Family history of T1D in distant relative: } \\
\begin{array}{cc}\text { +ve } & \text { No }(\%) \\
\text {-ve } & \text { No }(\%)\end{array}\end{array}$ & $\begin{array}{l}25(41.6 \%) \\
35(58.4 \%)\end{array}$ & $\begin{array}{l}7(11.6 \%) \\
53(88.4 \%)\end{array}$ & 0.18 \\
\hline $\begin{aligned} \text { Consanguinity: }+ \text { ve } & \text { No }(\%) \\
\text {-ve } & \text { No }(\%)\end{aligned}$ & $\begin{array}{l}24(40 \%) \\
36(60 \%)\end{array}$ & $\begin{array}{l}20(33.4 \%) \\
40(66.6 \%)\end{array}$ & 0.45 \\
\hline
\end{tabular}

This table shows insignificant differences between group I and group II regarding family history variables where $(\mathrm{P}>0.05)$.

\section{Discussion}

As regards T1D, autoimmunity is considered the major factor in the pathophysiology. In a genetically susceptible individual, viral infection may stimulate the production of antibodies against a viral protein that triggers an autoimmune response against antigenically similar beta cell molecules ${ }^{(\mathbf{6}}$.

The aim of this study was to screen for Islet cell antibodies in nondiabetic siblings of children with T1D.

Concerning the results of this study, Table (1) showed insignificant differences between group I and group II regarding age, gender, weight, height, and BMI centiles. In this study 33 (55\%) of the group, I children were from rural families and $27(45 \%)$ were urban. This disagreed with Borchers et al., ${ }^{(7)}$ who stated that higher socioeconomic status and the increase in the degree of urbanization are among the environ- mental factors that play a role in the rising incidence of T1D.

Table (2) showed insignificant differences between group I and group II regarding family history, family size, birth order, parental education, or occupation. In this table, as regard birth order, $12(20 \%)$ were $1^{\text {st }}$ birth order, 22 $(36.6 \%)$ were $2^{\text {nd }}$ birth order, $13(21.7 \%)$ were $3^{\text {rd }}$ birth order and $13(21.7 \%)$ were more than $3^{\text {rd }}$ birth order.

We found that 24 (40\%) of group I results from a consanguineous marriage. This disagrees with Lebenthal et al., ${ }^{(8)}$, who suggested that there was a relatively high degree of familial clustering among patients with T1D.

This was in agreement with American Diabetes Association (9) where it was stated that in siblings the relative expected insulin deficiency, due to the slightly expected B-cell Siblings of Children with Type I Diabetes Mellitus 
destruction, decreases the body ability to convert glucose into glycogen, which in turn makes it difficult to remove excess glucose from the blood, this lead to slightly increasing in plasma glucose.

Moreover, in table (5), $\mathrm{HbA} 1 \mathrm{c} \%$ was significantly higher in the first degree of T1D than the control group. This was in agreement with (Svensson et al., 2005) who found that increased plasma glucose causes red blood cells hemoglobin to join with glucose in the blood, becoming 'glycated'.

Regarding Islet cell antibodies, table (6) showed that group I had significant higher percentage of ICA positivety than the control group $(\mathrm{P}=0.004)$. This was in accordance with Watkins et al., ${ }^{(10)}$ and Salama et al., (2016) who found that islet cells antibodies were significantly higher among the relatives of the diabetics compared to healthy controls.

Moreover, Watkins et al., (2014) stated that ICA positivity can detect individuals at greater risk for T1D.

\section{Recommendations}

- There must be a wide immunogenetic screening of non-diabetic siblings of T1Dpatients to identify individuals at risk of T1D.

- There must be an extensive study on different antibodies rather than ICA

- Further follow-up of those with positive antibodies to predict progression of their levels or progression to overt clinical diabetes.

\section{References}

1. Akhrass F, Skinner N, Boswell $\mathrm{K}$ and Travis L. Evolving trends in insulin delivery: In pursuit of improvements in diabetes management. American Health \& Drug Benefits.2010;3(2):117-22.

2. Alemzadeh R. and Ali O. Diabetes Mellitus. In: Kliegman RM. ed. Kliegman: Nelson Textbook of Pediatrics. $19^{\mathrm{TH}}$ ed. Philadelphia, Pa: Saunders.2011; chap 583.

3. Atkinson MA and Maclaren NK Islet cell autoantigens in insulin-dependent diabetes. J Clin Invest.1993; 92(4):1608-16.

4. Bingley PJ Interactions of age, islet cell antibodies, insulin autoantibodies, and first phase insulin response in predicting risk of progression to IDDM in ICA+ relatives: the ICARUS data set. Islet Cell Antibody Register Users Study. Diabetes.1996; 45(12):1720-8.

5. Chou K.L., Galetta S.L., Liu G.T., Volpe N.J., Bennett J.L. and Asbury A.K. Acute ocular motor mononeuropathies: a prospective study of the roles of neuroimaging and clinical assessment. J. Neurol. Sci. 2004; 15: 35-9.

6. Evans D.J., Pritchard-Jones K. and Trotman-Dickenson B. Insulin oedema. Postgrad. Med. J.1986; 62: 665-8.

7. Hammes H.P., Kerner W. and Hofer S., et al., (2011) Diabetic retinopathy in type 1 diabetes-a contemporary analysis of 8,784 patients. Diabetologia.2011; 54(8):1977-84.

8. Kawasaki E, Takino H, Yano M, Uotani S, Matsumoto K and Takao Y. Autoantibodies to glutamic acid decarboxylase in patients with IDDM and autoimmune thyroid disease. Diabetes 1994;43:80-6.doi: 10.2337/diab.43.1.80.

9. Knip M, Korhonen S, Kulmala $\mathrm{P}$ et al., Prediction of type 1 diabetes in the general population.Diabetes Care.2010:33:1206-12. 